\title{
DEVELOPING SPATIAL ABILITY USING 3D MODELING IN LOWER SECONDARY SCHOOL
}

\author{
Andrej Šafhalter \\ Lower Secondary School Anice Černejeve Makole, Slovenia \\ E-mail: andrej.safhalter@os-makole.si
}

Srečko Glodež, Boris Aberšek, Karin Bakračevič Vukman

University of Maribor, Maribor, Slovenia

E-mail: srecko.glodez@uni-mb.si, boris.abersek@uni-mb.si, karin.bakracevic@um.si

\begin{abstract}
In recent years $3 D$ modeling has been increasingly utilized during product design in lower secondary schools as well. Its greatest advantage over classical technical drawing and 2D drawing software lies in the fact students are able to observe the object they are designing from all the viewpoints of a virtual three-dimensional space. Since thinking and visualization in the process of object design also appear in three dimensions, the mental manipulation and guesswork required from students in order to add another dimension to an object pictured on a level plane are no longer necessary.

Additionally, 3D modeling has a range of contributions to the cognitive development of children, which was also the subject of this research. The central question raised was whether students are able to improve their spatial ability by using modeling tools. The research included 196 students aged between 1115 years, of which 95 were placed in the experimental group and 101 in the control group. Spatial ability was measured using pre-test and post-test.
\end{abstract}

Key words: $3 D$ modeling, cognitive development, spatial ability, visualization.

\section{Introduction}

For many years technical design classes in Slovenian lower secondary schools used ciciCAD software or manual drawing with a pencil on paper in various projections. In recent years 3D computer modeling has been gaining ground. The biggest advantage of 3D modeling in comparison with technical drawing and drawing using the ciciCAD tool is the fact that students are able to see the object they are designing from all angles in a virtual three-dimensional space. When designing a product one thinks three-dimensionally (Field, 2004) and has no need of mental manipulation and of imagining how an object shown in a plane on a piece of paper or on a computer screen would look like from different sides. When making a product students must once again perform a transformation, this time from $2 \mathrm{D}$ to $3 \mathrm{D}$. When designing with $3 \mathrm{D}$ modelers, one does not encounter such problems. If isometric projection is a virtual display of a three-dimensional image of an object on a two-dimensional medium, then 3D modeling is a portrayal of a model in a virtual three-dimensional space.

During a visual presentation of a product or visualization students can show what the object they are about to make will look like. Thus a non-existent object can be visibly presented, since the idea for the product has been mentally visualized. The levels leading up to a technical realization are (Mancini, 2011): perception, memory, thought, imagination, mental visualization and technical realization. Imagination is defined as fantasy, creative imagination and the ability 
Andrej ŠAFHALTER, Srečko GLODEŽ, Boris ABERŠEK, Karin BAKRAČEVIČ VUKMAN. Developing Spatial Ability Using 3D Modeling in Lower Secondary School

OF EDU

PROBLEMS

IN THE $21^{\text {st }}$ CENTURY

Volume 61,2014

to visualize (Antič, 2011). As stated by Mancini (Mancini, 2011), imagination is "an ability that enables creative thinking. In this process explicit notions become imaginative images which the creative mind can more easily operate with, combine and select" (Mancini, 2011, p. 70). Visualization has two meanings: it is the activity, process or method of creating that which one sees and something that presents the final goal of visualization in the process of creating the visible. 3D modeling presents 3D computer visualization in a virtual three-dimensional space. In technical design classes it enables students to view an object from a random angle.

An experiment conducted in 2008 among forty technical school students aged 18 to 20 (Martin-Dorta, Saorin and Contero, 2008), showed that 3D modeling improves spatial ability.

Also interesting is a comparison of spatial ability between genders and its improvement due to 3D modeling. According to certain research studies (Martin-Dorta, Saorin and Contero, 2008) and findings (Sorby, 2006; Sorby, 2007; Sorby, 2009), males possess better spatial abilities, whereas according to others (Basham, 2007; Koch, 2006; Titze, Heil and Jansen, 2008), the differences are minimal or non-existent.

As Gardner states (Gardner, 2010), better spatial abilities of males could be attributed to evolutionary factors. Hunting, foraging for food and bringing it back to the community was a predominantly male activity and it is reasonable to expect it could have contributed to the development of spatial abilities, though this remains speculation (Kolb and Whishaw, 2014). Since no tests were conducted at the time, exactly why differences occurred in the evolution of the male and female brain will likely never be known. McGee (McGee, 1979) claimed that spatial ability was inherited through a recessive gene on the X-chromosome. Some explanations (Kolb and Whishaw, 2003) state that spatial ability might be influenced by hormones, which is supposedly reflected more in adults than in children, since great hormonal changes take place during puberty. The factors influenced by hormones (Kolb and Whishaw, 2014) are located in the brain, most likely in the neuron networks that are otherwise responsible for spatial ability. The male and female brains (Zaidi, 2010) also have different anatomy. Thus, in the male brain the right hemisphere is thicker than in the female one, which could explain why males possess better spatial ability. On the other hand the left hemisphere, which is responsible for language, is thicker in the female brain. Research (Sabbatini, 2000) has also shown that the right inferior parietal lobule is connected with the understanding of spatial relations and relations among individual parts of objects, whereas the left lobule is connected with the perception of time, speed and mental manipulation or rotation of 3D objects in the brain.

The benefits of 3D modeling for the cognitive development of a child as regards spatial ability are presented in the described research. Thus the basic question is whether 3D modeling has a positive impact on the spatial ability of students aged between 11 and 15 . Furthermore, the aim is to determine spatial ability with regard to the gender of the students and the respective differences in the development of this ability due to 3D modeling.

\section{Methodology of Research}

\section{General Research Characteristics}

An experimental research was conducted to test the efficiency of the 3D modeling extracurricular activity from the aspect of the spatial ability of male and female students, namely: spatial ability in the case of shapes rotated in a plane and spatial ability in the case of rotations in a virtual 3D space. It examined the initial state from the aspect of the relevant factors connected with the students as individuals and with the effects of the experiment (differences in achievements at the post-test of spatial ability between the experimental and the control group, the progress of students of the experimental group from the aspect of spatial ability, and differences between genders). This didactic experiment lasted two school years: 2011/2012 and 2012/2013. 
In each of the above-mentioned school years different students participated in the control and experimental group. The experiment was conducted in the technical field.

\section{Sample of Research}

The research involved 196 students from 11 Slovenian lower secondary schools. Of these, 95 (48.5\%) presented the experimental group and $101(51.5 \%)$ the control group. Males were slightly predominant; there were 107 of them, which stood for $54.6 \%$, whereas the number of females was 89 or $45.4 \%$.

The sample was non-random, students were chosen from schools that conducted the extracurricular activity of 3D modeling. Statistical analysis was performed on a representative sample of 196 students.

\section{Instrument and Procedures}

The study was based on an experimental approach to empirical pedagogical research. A single-factor experiment was conducted with groups of students as control groups. The experimental factor had two modalities: a control group, which contained students who were not taking part in the 3D modeling extracurricular activity and who used the "classic" method during the product design stage, i.e. a pencil and a sheet of paper, and an experimental group, which contained students who were participating in the 3D modeling extracurricular activity. During the extracurricular activity they made models based on a rectangular and isometric projection, and objects from the environment and buildings. The experimental group of students used the SketchUp software tool for 3D modeling.

Prior to the start of the experiment the spatial ability of students was tested using the hybrid spatial ability test 1 (pre-test). After the experiment had been conducted the spatial ability of students was likewise tested using the hybrid spatial ability test 2 (post-test). Both tests contained the same sets of assignments, 14 in total, with a maximum of 16 points. The spatial ability test was compiled based on the known groups of spatial ability tests: PRT (Picture Rotation Test), Form Board Test, The Punched Holes Test (Paper Folding Test), DAT: SR (Differential Aptitude Test: Space Relations), The Surface Development Test, MRT (Mental Rotation Test), PSVT: R (Purdue Spatial Visualization Test: Rotations) assignments, where mental manipulation had to be applied in order for these assignments to be solved correctly. The tests determined the understanding of relations between individual geometric shapes rotated in a plane and between objects rotated in a virtual 3D space.

To establish the reliability of the pre-test and post-test, the Cronbach alpha $(\alpha)$ coefficient was used along with the outcome of factorization, taking into account the rule $r_{t t} \geq \sqrt{ } h^{2}$.

The established Cronbach coefficient of 0.745 and percentage of variance explained by common factors of $57.5\left(\mathrm{r}_{\mathrm{tt}} \geq 0,758\right)$ shows that the tests of spatial ability were within the boundaries of acceptable reliability. Objectivity was assured by providing testers with precise testing instructions (introductory instructions, range of allowed tools, withholding of assistance, criticism or commendation). Students were allowed 35 minutes to solve the test. The criteria of the test assessment were unified. A trial test was done during pilot research in the school year 2010/2011, and included 22 students (10 male and 12 female) of which 14 represented the experimental group and 8 the control group.

\section{Data Analysis}

The data were processed with SPSS software for statistical analysis. The following procedures were used: frequency distributions ( $\mathrm{f}, \mathrm{f} \%), \mathrm{t}$ - independent samples test, $\mathrm{t}$ - dependent samples test. 
Andrej ŠAFHALTER, Srečko GLODEŽ, Boris ABERŠEK, Karin BAKRAČEVIČ VUKMAN. Developing Spatial Ability Using 3D Modeling in Lower Secondary School

OF EDUCATI

IN THE $21^{\text {st }}$ CENTURY Volume 61, 2014

116

\section{Results of Research}

The differences between the experimental and the control group in the total score of the pre-test of spatial ability are shown in Table 1.

Table 1. The result of the t-test for examining the differences in the total spatial ability score between students of the experimental group (EG) and the control group (CG) prior to the experiment.

\begin{tabular}{|c|c|c|c|c|c|c|c|}
\hline \multirow{2}{*}{ Group } & \multirow{2}{*}{$\mathrm{N}$} & \multirow{2}{*}{$\begin{array}{l}\text { Arithmetic } \\
\text { mean }\end{array}$} & \multirow{2}{*}{$\begin{array}{l}\text { Standard } \\
\text { Deviation }\end{array}$} & \multicolumn{2}{|c|}{$\begin{array}{l}\text { Test for homogeneity of vari- } \\
\text { ances }\end{array}$} & \multicolumn{2}{|c|}{$\begin{array}{l}\text { Test for differences in arith- } \\
\text { metic means }\end{array}$} \\
\hline & & & & $F$ & Sig. & $t$ & $\begin{array}{l}\text { Sig. } \\
\text { (2-tailed) }\end{array}$ \\
\hline EG & 95 & 7.62 & 2.718 & \multirow{2}{*}{0.002} & \multirow{2}{*}{0.965} & \multirow{2}{*}{-1.956} & \multirow{2}{*}{0.052} \\
\hline$C G$ & 101 & 8.38 & 2.686 & & & & \\
\hline
\end{tabular}

The hypothesis on the homogeneity of variances, on which the use of a t-test had been based, was justified $(\mathrm{F}=0.002 ; \mathrm{Sig}$. $=0.965)$. As demonstrated by the result of the $\mathrm{t}$-test at the pre-test of spatial ability, there were no statistically significant differences between the students of the experimental group and the control group $(t=-1.956$; Sig. $(2$-tailed $)=0.052)$.

Table 2 shows the differences at the post-test of spatial ability for students of the experimental and the control group.

Table 2. The result of the t-test for examining the differences in the total spatial ability score between students of the experimental group (EG) and the control group (CG) after the experiment.

\begin{tabular}{|c|c|c|c|c|c|c|c|}
\hline \multirow{2}{*}{ Group } & \multirow{2}{*}{$\mathrm{N}$} & \multirow{2}{*}{$\begin{array}{l}\text { Arithmetic } \\
\text { mean }\end{array}$} & \multirow{2}{*}{$\begin{array}{l}\text { Standard } \\
\text { Deviation }\end{array}$} & \multicolumn{2}{|c|}{$\begin{array}{l}\text { Test for homogeneity of vari- } \\
\text { ances }\end{array}$} & \multicolumn{2}{|c|}{$\begin{array}{l}\text { Test for differences in arith- } \\
\text { metic means }\end{array}$} \\
\hline & & & & $\mathrm{F}$ & Sig. & $t$ & $\begin{array}{l}\text { Sig. } \\
\text { (2-tailed) }\end{array}$ \\
\hline$E G$ & 95 & 10.32 & 2.826 & \multirow{2}{*}{5.292} & \multirow{2}{*}{0.022} & \multirow{2}{*}{6.393} & \multirow{2}{*}{0.000} \\
\hline$C G$ & 101 & 7.39 & 3.566 & & & & \\
\hline
\end{tabular}

Since the hypothesis on the homogeneity of variances, on which the t-test had been based, was not justified $(\mathrm{F}=5.292$; Sig. $=0.022)$, the result of the approximation method of the $\mathrm{t}$-test was referred to. It showed $(\mathrm{t}=6.393$; Sig. $(2$-tailed $)=0.000)$ that a statistically significant difference did exist between the students of the experimental and the control group in the total score of the spatial ability test.

The progress in the spatial ability of students of the experimental group at the post-test in comparison with the pre-test is shown in Table 3. 
Andrej ŠAFHALTER, Srečko GLODEŽ, Boris ABERŠEK, Karin BAKRAČEVIČ VUKMAN. Developing Spatial Ability Using 3D Modeling in Lower Secondary School

Table 3. The result of the t-test for examining the differences in the spatial ability score between the initial and final state.

\begin{tabular}{|c|c|c|c|c|c|c|}
\hline \multirow{2}{*}{$\begin{array}{l}\text { Test } \\
\text { (total) }\end{array}$} & \multirow{2}{*}{ N } & \multirow{2}{*}{ Arithmetic mean } & \multirow{2}{*}{$\begin{array}{l}\text { Standard Devia- } \\
\text { tion }\end{array}$} & \multicolumn{3}{|c|}{ Test for differences in arithmetic means } \\
\hline & & & & $t$ & df & $\begin{array}{l}\text { Sig. } \\
\text { (2-tailed) }\end{array}$ \\
\hline Pre-test & 95 & 7.62 & 2.718 & \multirow{2}{*}{-10.818} & \multirow{2}{*}{94} & \multirow{2}{*}{0.000} \\
\hline Post-test & 95 & 10.32 & 2.826 & & & \\
\hline
\end{tabular}

The result of the t-test for differences in arithmetic means showed that there were statistically significant differences between the initial and final state of the total spatial ability score $(\mathrm{t}$ $=-10.818 ; \mathrm{df}=94 ;$ Sig. $(2$-tailed $)=0.000)$.

The differences between the results of the pre-test and post-test of spatial ability for both genders are shown in Table 4.

Table 4. The result of the t-test for examining the differences in scores between the initial and final state for males (M) and for females (F).

\begin{tabular}{|c|c|c|c|c|c|c|}
\hline \multirow{2}{*}{ Gender } & \multirow{2}{*}{ Test } & \multirow{2}{*}{$\mathrm{N}$} & \multirow[t]{2}{*}{ Arithmetic mean } & \multirow{2}{*}{ Standard Deviation } & \multicolumn{2}{|c|}{$\begin{array}{l}\text { Test for differences in arithmetic } \\
\text { means }\end{array}$} \\
\hline & & & & & $t$ & $\begin{array}{l}\text { Sig. } \\
\text { (2-tailed) }\end{array}$ \\
\hline \multirow{2}{*}{ M } & Pre-test & 63 & 7.78 & 2.721 & \multirow{2}{*}{-7.727} & \multirow{2}{*}{0.000} \\
\hline & Post-test & 63 & 10.16 & 2.835 & & \\
\hline \multirow{2}{*}{$F$} & Pre-test & 32 & 7.31 & 2.729 & \multirow{2}{*}{-8.125} & \multirow{2}{*}{0.000} \\
\hline & Post-test & 32 & 10.63 & 2.826 & & \\
\hline
\end{tabular}

The result of the t-test for differences in arithmetic means showed that there were statistically significant differences between the pre-test and post-test of spatial ability both in the case of men $(t=-7.727 ;$ Sig. $(2$-tailed $)=0.000)$ and in the case of females $(t=-8.125 ;$ Sig. (2-tailed) $=0.000)$.

At the spatial ability test conducted prior to the experiment, the students of the control group scored a higher point average $(=8.38)$ than those of the experimental group $(=7.62)$. At the post-test the difference between the students of the experimental $(=10.32)$ and the control ( $=7.39$ ) group was greatly to the advantage of the experimental group. The graphic presentation (Figure 1) of the pre-test and post-test shows that the scores of the experimental group (EG) surpassed those of the control group (CG) at all three levels (parts of the test where objects were rotated in a plane or in a virtual 3D space and in the total number of points). 
Andrej ŠAFHALTER, Srečko GLODEŽ, Boris ABERŠEK, Karin BAKRAČEVIČ VUKMAN. Developing Spatial Ability Using 3D Modeling in Lower Secondary Schoo

OF EDUCATION

IN THE $21^{\text {st }}$ CENTURY

Volume 61,2014

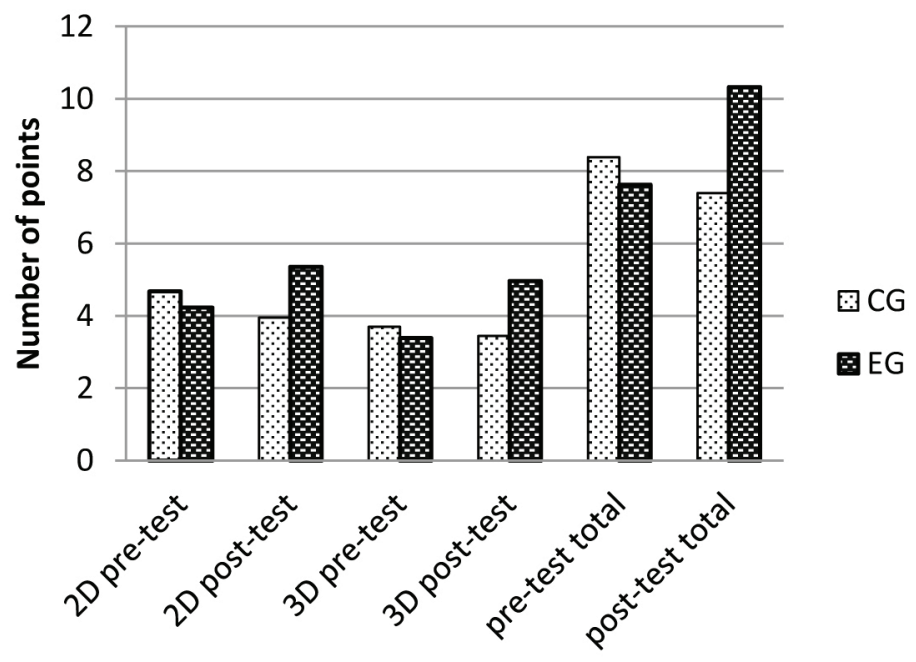

Figure 1: Arithmetic mean of attained points at individual levels of the pre-test and post-test of spatial ability of the control group (CG) and the experimental group (EG).

On average the males of the experimental group scored 2.38 points more at the post-test than at the pre-test, whereas females scored 3.32 more points. It has been ascertained that both males and females showed progress at the post-test in comparison with the pre-test. In general, the activity had a positive impact on both genders regarding spatial ability.

\section{Discussion}

As a previous group of authors already established (Martin-Dorta, Saorin and Contero, 2008), 3D modeling can have a positive impact on the development of spatial ability, though their research was based on students aged 18 to 20 years as opposed to the research described here. This makes it highly probable that the tested students were already in the phase of formallogical thinking (Bakračevič, 2000), as opposed to research in which participating students were aged $11-15$. Furthermore, in the activity of 3D modeling, the role of the teacher certainly has a considerable influence on the process, since familiarization with the modeler is quicker and, as Basham established (Basham, 2007), teacher assistance is a deciding factor in the students' achievement of added value.

According to data from literature (Gardner, 2010; McGee, 1979; Sorby, 2007; Sorby, 2009), a hypothesis was proposed stating that males have better spatial abilities compared to females. Nonetheless, it has been shown that there are no statistically characteristic differences, as supported by the findings of other authors as well (Koch, 2006; Titze, Heil and Jansen, 2008; Kolb in Whishaw, 2014). If hormones do affect spatial ability (Kolb and Whishaw, 2003), such an influence would express itself during different age periods. Since females are affected by the activity of sexual hormones at a somewhat earlier age (Brizendine, 2007), this could be the reason the pre-test did not establish statistically characteristic differences, with females even scoring slightly better results on average. 


\section{Conclusions}

The main finding of the pedagogical experiment is the proven positive impact of 3D modeling on the spatial ability of $s$ in lower secondary school, ages 11 to 15 . Progress in spatial ability due to 3D modeling was detected in both genders, and was even greater in the case of females. The described research involved students from eleven to fifteen years of age; further studies could try to determine the progress in spatial ability and its progress due to $3 \mathrm{D}$ modeling in younger students as well, since it is known that spatial ability develops gradually and depends on several factors. In the 2013/2014 school year the elective subject of drawing in geometry and technical class began to be implemented in Slovenia for the first time in accordance with a renewed curriculum and encompasses solely 3D modeling. The curriculum has been approved by the Ministry of Education, Science and Sport.

\section{Acknowledgments}

The authors acknowledge the support of the Ministry of Education, Science and Sport of Republic of Slovenia and European Social Fund in the frame of the Project: "Innovative pedagogy 1: 1 in the light of competences of the 21st century" on Faculty of Natural Sciences of University of Maribor.
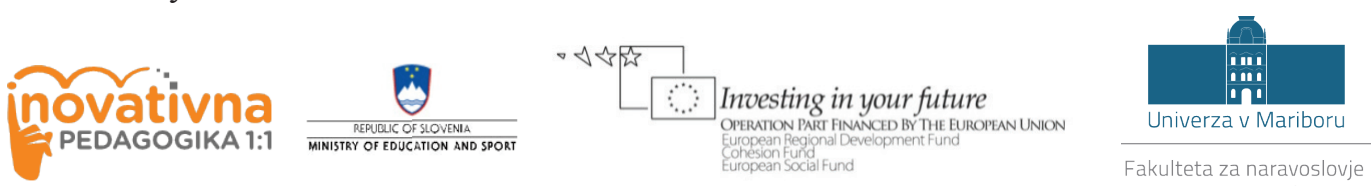

in matematiko

\section{References}

Antič, I. (2011). Slovar tujk [Dictionary of Foreign Words]. Tržič: Učila International.

Bakračevič Vukman, K. (2000). Razvoj mišljenja v odrasli dobi [Cognitive Development in the Adult Age]. Maribor: Pedagoška fakulteta Maribor.

Basham, K. Lynn. (2007). The effects of 3-dimensional CADD modeling software on the development of spatial ability of ninth grade Technology Discovery students. Louisiana State University and Agricultural \& Mechanical College.

Brizendine, L. (2007). Ženski možgani [The Female Brain]. Ljubljana: Modrijan.

Field, D. A. (2004). Education and training for CAD in the auto industry. Computer-Aided Design, 36 (14), 1431-1437.

Gardner, H. (2010). Razsežnost uma: Teorija o več inteligencah [The Scope of the Mind: Multiple Intelligence Theory]. Ljubljana: Založba Tangram.

Koch, D. S. (2006). The effects of solid modeling and visualization on technical problem solving. Virginia Polytechnic Institute and State University.

Kolb, B., Whishaw, I. Q. (2003). Fundamentals of human neuropsychology, Fifth Edition. New York: Worth publishers.

Kolb, B., Whishaw, I. Q. (2014). An introduction to brain and behavior, Fourth Edition. New York: Worth publishers.

Mancini, L. (2011). Vizualizacije filozofskih konceptov [Visualization of Philosophical Concepts]. Ljubljana: Akademija za likovno umetnost in oblikovanje v Ljubljani.

Martin-Dorta, N., Luis Saorin, J., Contero, M. (2008). Development of a fast remedial course to improve the spatial abilities of engineering students. Journal of Engineering Education, 97 (4), 505-513.

McGee, M. G. (1979). Human spatial abilities: Psychometric studies and environmental, genetic, hormonal, and neurological influences. Psychological Bulletin, 86, 889-918.

Sabbatini, R. M. E. (2000). Are there differences between the brains of males and females? Brain \& Mind Magazine, October/December.

Sorby, S. A. (2006). Developing 3D spatial skills for K-12 students. Engineering Design Graphics Journal, 70 (3), 1-11. 
Andrej ŠAFHALTER, Srečko GLODEŽ, Boris ABERŠEK, Karin BAKRAČEVIČ VUKMAN. Developing Spatial Ability Using 3D Modeling in Lower Secondary Schoo

PROBLEMS

OF EDUCATION

IN THE $21^{\text {st }}$ CENTURY

Volume 61,2014

Sorby, S. A. (2007). Developing 3D spatial skills for engineering students. Australasian Journal of Engineering Education, 13 (1), 1-11.

Sorby, S. A. (2009). Educational research in developing 3-D spatial skills for engineering students. International Journal of Science Education, 31 (3), 459-480.

Titze, C., Heil, M., Jansen, P. (2008). Gender differences in the mental rotations test (MRT) are not due to task complexity. Journal of Individual Differences, 29 (3), 130-133.

Zaidi, Z. F. (2010). Gender differences in human brain: A review. The open Anatomy Journal, 2, 37-55.

Advised by Laima Railienè, University of Šiauliai, Lithuania

Received: June 18, 2014

Accepted: August 26, 2014

Andrej Šafhalter

Lower Secondary School Anice Černejeve Makole, Slovenia.

E-mail: andrej.safhalter@os-makole.si

Srečko Glodež

PhD., Professor, Faculty of Natural Sciences and Mathematics, University of Maribor, Koroška 160, 2000 Maribor, Slovenia.

E-mail: srecko.glodez@uni-mb.si

Boris Aberšek

PhD, Professor, Head of Institute for Contemporary Technology, Faculty of Natural Sciences and Mathematics, Koroška 160, 2000 Maribor, Slovenia.

E-mail: boris.abersek@um.si

Website: http://tehnika.fnm.uni-mb.si

Karin Bakračevič Vukman

PhD., Professor, Department of Psychology, University of Maribor, Koroška

160, 2000 Maribor, Slovenia.

E-mail: karin.bakracevic@um.si 